\title{
Stone Cell Frequency and Cell Area Variation of Crisp and Standard Texture Southern Highbush Blueberry Fruit
}

\author{
Kendra M. Blaker and James W. Olmstead ${ }^{1}$ \\ Horticultural Sciences Department, University of Florida, 2211 Fifield Hall, Gainesville, FL 32611
}

\begin{abstract}
AdDitional INDEX wORDs. epidermis, histology, microstructure, sclereids, Vaccinium corymbosum
Abstract. Sclerified stone cells with a thick and lignified secondary cell wall are known to vary in number among cultivars of northern highbush blueberry (Vaccinium corymbosum) and rabbiteye blueberry (Vaccinium virgatum), and may contribute to fruit texture. Variation in cell size can also contribute to differences in fruit firmness. Fruit from nine southern highbush blueberry [SHB ( . corymbosum interspecific hybrids)] cultivars determined by sensory and instrumental analysis to vary in fruit texture were harvested at mature green and ripe blue developmental stages. Paraffin embedded 12- $\mu \mathrm{m}$ sections were stained with Safranin $O$ and Aniline Blue and microstructure was examined by light microscopy. Stone cells within $\approx 1.2 \mathrm{~mm}$ of the epidermis were counted and cell area was measured in the epidermal layer and three layers beneath the epidermis of the fruit. There was a significant difference in cell area among genotypes and cell layers for mature green fruit and among texture types, genotypes, and cell layers for ripe blue fruit. The average number of stone cells in a single berry ranged from zero to 95 among cultivars. Significant differences in the number of stone cells just below the epidermal layer did not correspond to standard or crisp fruit texture.
\end{abstract}

Several fresh-market fruit species have textures that range from soft to crisp, including apple (Malus $\times$ domestica), grape (Vitis vinifera), peach (Prunus persica), and sweet cherry (Prunus avium) (Batisse et al., 1996; Ghiani et al., 2011; Sato et al., 2006; Tong et al., 1999). Crisp fruit texture has been described in the southern highbush blueberry cultivars, Bluecrisp, Dolores, Reveille, and Sweetcrisp, and the northern highbush blueberry cultivar Hortblue Poppins (Clark and Finn, 2010; Okie, 1999; Scalzo et al., 2009). In addition, many current selections in the University of Florida SHB breeding program are also considered to have a crisp phenotype (Blaker et al., 2014). Berries with this crisp texture are of particular interest as a result of their enhanced eating quality, prolonged postharvest life, and potential value for mechanical harvesting for fresh-marketed blueberries (Mehra et al., 2013; Padley, 2005; Takeda et al., 2013).

Several cellular components contribute to overall fruit texture, including cell type, size, shape, packing, cell to cell adhesion, extracellular space, and cell wall thickness (Harker et al., 1997). Parenchyma cells are the most numerous type of cells in the flesh of blueberry fruit and have thin, non-lignified cell walls and a large, mostly water-filled vacuole (Harker et al., 1997). The epidermis is composed of specialized parenchyma cells that have thickened primary cell walls and are covered by a cuticle consisting of cutin and associated waxes (Esau, 1977). Collenchyma cells and phloem elements have thickened primary cell walls that provide tensile strength to surrounding tissues. Xylem and sclerenchyma cells such as fibers and

Received for publication 25 Feb. 2014. Accepted for publication 13 June 2014. This work was supported by funding from the Florida Department of Agriculture and Consumer Services and USDA-NIFA Specialty Crop Research Initiative Award \# 2008-51180-19579.

We thank Straughn Farms for the use of their plant material and James Colee for statistical consulting.

${ }^{1}$ Corresponding author. E-mail: jwolmstead@ufl.edu. sclereids have thick and lignified secondary cell walls that are dead at maturity and give support (Harker et al., 1997).

Cell size varies with different cell types during ripening. Fruit development in blueberry follows a double-sigmoid growth pattern in which the pericarp initially increases in volume (Stage I), then the embryo develops while pericarp growth slows down (Stage II), and ripening occurs in conjunction with a final expansion in pericarp size (Stage III) (Godoy et al., 2008). In rabbiteye blueberry, differences in cell number were apparent in the ovary of different genotypes at bloom (Johnson et al., 2011). Shortly after anthesis, mesocarp cells in the ovary tissue that will develop into blueberry fruit stop dividing and increase only in size as the fruit continues to develop and enlarge (Darnell et al., 1992; Johnson et al., 2011). Johnson et al. (2011) found within-genotype differences in fruit size to be highly correlated with cell number and not cell size, although mesocarp cells increased 18- to 21-fold in area. Cell size is much larger in the mesocarp than in the epidermal and hypodermal layers that together form the epicarp, where cell division occurs over a longer period of time during fruit expansion (Harker et al., 1997). Mann et al. (2005) compared instrumental measurements and sensory evaluations to cell number and size in apple and concluded that fruit with fewer cells per unit area in the apple cortex (mesocarp) were crisper than fruit with more cells per unit area. This may be the result of an increased likelihood for larger cells to burst rather than separate from neighboring cells as is believed to occur in crisptextured fruit with smaller sized cells and an increased surface area and higher proportion of cell wall material (Harker et al., 1997).

The amount of contact and/or space between neighboring cells is influenced by the shape and packing of cells (Harker et al., 1997). Batisse et al. (1996) observed that crisp-textured sweet cherries had more large intercellular spaces than those with soft texture. The degree to which adjacent cells separate during chewing also has an effect on its perceived texture. In the 
Table 1. Average cell area for each cell layer of standard and crisp texture southern highbush blueberry genotypes at the mature green and ripe blue stages of development. ${ }^{z}$

\begin{tabular}{|c|c|c|c|c|c|c|c|c|}
\hline \multirow[b]{3}{*}{ Genotype } & \multirow[b]{3}{*}{ Texture } & \multicolumn{7}{|c|}{ Avg cell area $\left(\mu \mathrm{m}^{2}\right)$} \\
\hline & & \multicolumn{3}{|c|}{ Ripe blue } & \multicolumn{4}{|c|}{ Mature green } \\
\hline & & 1 & 2 & 3 & 1 & 2 & 3 & 4 \\
\hline FL06-244 & Crisp & $712 a^{y}$ & $1357 \mathrm{ab}$ & $1866 \mathrm{ab}$ & $718 \mathrm{a}$ & $1417 \mathrm{a}$ & $1782 \mathrm{a}$ & $3157 \mathrm{ab}$ \\
\hline 'Springhigh' & Standard & $661 \mathrm{a}$ & $1148 \mathrm{bc}$ & $1380 \mathrm{~b}$ & $558 \mathrm{~b}$ & 1149 a & $1429 \mathrm{a}$ & $2483 \mathrm{ab}$ \\
\hline FL06-245 & Standard & $614 \mathrm{ab}$ & $1302 \mathrm{ab}$ & $1653 \mathrm{~b}$ & $436 \mathrm{~b}$ & $1083 a b$ & $1901 \mathrm{a}$ & $3555 \mathrm{a}$ \\
\hline FL98-325 & Crisp & $610 \mathrm{ab}$ & $1264 \mathrm{ab}$ & $1873 \mathrm{ab}$ & $584 \mathrm{~b}$ & $1112 \mathrm{ab}$ & $1586 \mathrm{a}$ & $2701 \mathrm{ab}$ \\
\hline 'Windsor' & Standard & $582 \mathrm{ab}$ & $1256 \mathrm{ab}$ & $1689 \mathrm{~b}$ & $536 \mathrm{~b}$ & $998 \mathrm{ab}$ & $1393 \mathrm{a}$ & $2715 \mathrm{ab}$ \\
\hline 'Raven' & Standard & $521 \mathrm{ab}$ & $1126 \mathrm{bc}$ & $1837 \mathrm{ab}$ & $561 \mathrm{~b}$ & $929 \mathrm{ab}$ & $1307 \mathrm{a}$ & $2224 b$ \\
\hline FL07-100 & Crisp & $429 \mathrm{~b}$ & $787 \mathrm{c}$ & $1275 \mathrm{~b}$ & $470 \mathrm{~b}$ & $774 \mathrm{~b}$ & $1418 \mathrm{a}$ & $2703 \mathrm{ab}$ \\
\hline
\end{tabular}

${ }^{\mathrm{z}}$ The epidermal cell layer is represented as 1, the second outermost cell layer is marked 2, and the third and fourth layers are 3 and 4 , respectively. yTukey's honestly significant difference grouping for least square (LS) means. LS means with different letters within a column are significantly different at $P \leq 0.05$.

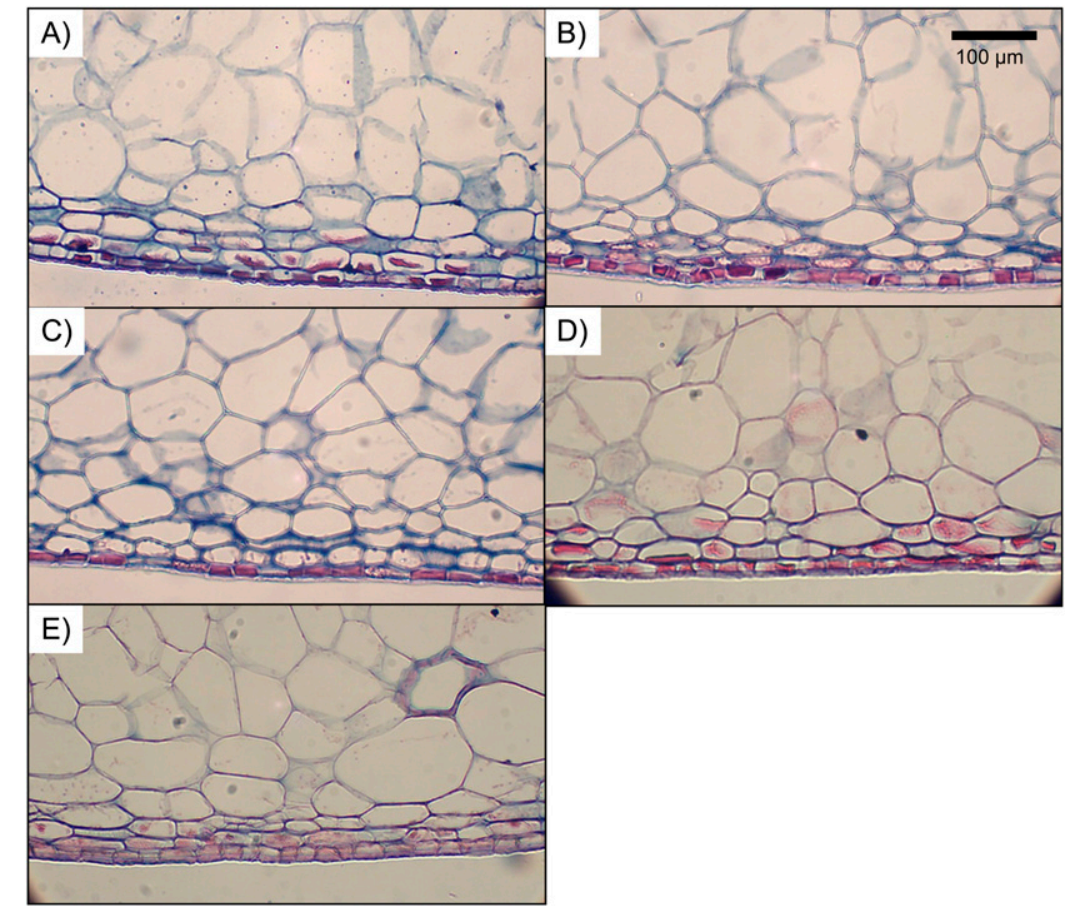

Fig. 1. Microscopic images of 12- $\mu \mathrm{m}$ sections from mature green fruit of standard texture southern highbush blueberry genotypes (100× magnification): (A) 'Springhigh', (B) 'Windsor', (C) 'Star', (D) FL06-245, (E) 'Raven'. Sections were stained with Safranin O and Aniline Blue.

process of chewing, force is applied to the fruit tissue until it fractures, which can occur by cell separation-as is the case with soft fruit such as banana (Musa sp.) — or by individual cell rupture in crisp fruit such as apple and watermelon (Citrullus lanatus) (Harker et al., 1997). Cell wall strength and cell-to-cell adhesion also contribute to whether cells separate or rupture (Harker et al., 1997).

Blueberry fruit develop from an inferior ovary. The epidermis originates from the floral calyx, and the epidermis and hypodermal layers contain pigmentation from anthocyanins and form the epicarp, commonly referred to as the peel or skin (Gough, 1994). The endocarp is composed of five carpels with 10 locules and five highly lignified placentae to which $\approx 50$ seeds are attached (Gough, 1994). The mesocarp is located between these layers and contains mostly parenchyma cells along with rings of vascular bundles and occasional sclerified stone cells that can be found $\approx 460$ to $920 \mu \mathrm{m}$ below the epidermis (Gough, 1983). These lignified cells with thick secondary cell walls can occur singly, doubly, or in clusters, and they bind neighboring parenchyma cells, which serve to strengthen their surrounding flesh tissue and may contribute to fruit firmness (Allan-Wojtas et al., 2001; Fava et al., 2006; Gough, 1983). Increased firmness just beneath the epidermal layer where initial rupture of the berry takes place could contribute to the crisp texture observed in some blueberry cultivars. Results of a trained sensory panel that evaluated the texture of several SHB genotypes ranging from soft to crisp also suggested that the crisp texture may be related to the blueberry peel or skin (Blaker et al., 2014). Genotypes receiving high sensory scores for crisp texture by the panel were often also rated for having a high level of skin toughness. Together these findings suggest that crisp texture is likely associated with differences in or near the epidermal layer of the berry. The objective of this study was to perform a histological analysis of cell type, area, and structure of the outermost cell layers of standard and crisp-textured fruit from nine SHB genotypes.

\section{Materials and Methods}

Plant material. Fruit were harvested from nine SHB genotypes that were developed by breeders at the University of Florida and were being grown on commercial farms in Windsor, FL, and Waldo, FL. A large population of fruit was harvested to select individual fruit that were similar in size. Genotypes were selected based on results from sensory evaluations and instrumental measures of standard and crisp fruit texture (Blaker et al., 2014). Four crisp texture genotypes (FL06-244, FL98-325, FL07100 , and 'Sweetcrisp') and four standard texture genotypes 


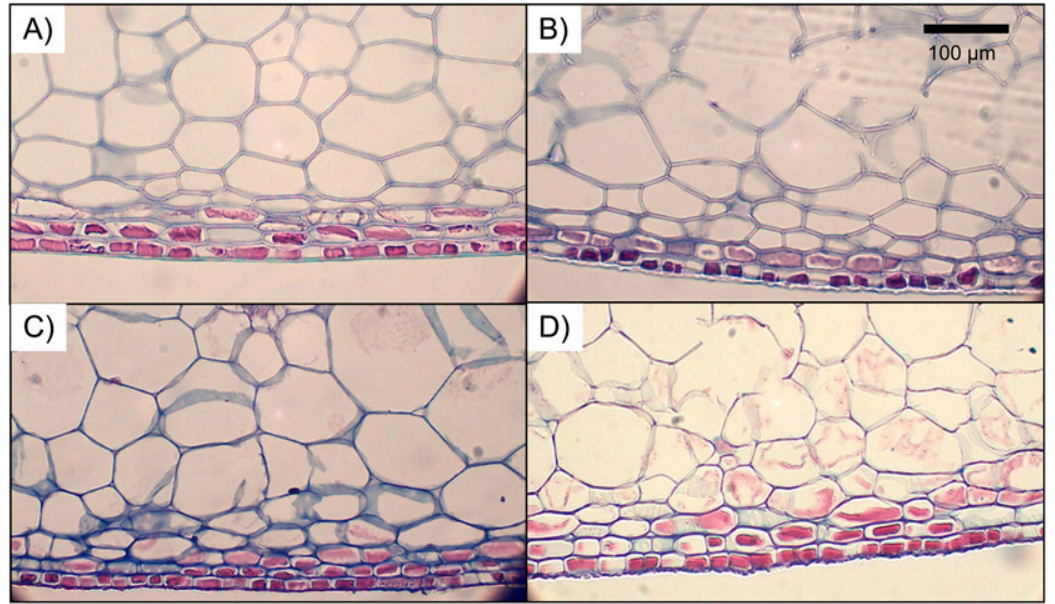

Fig. 2. Microscopic images of $12-\mu \mathrm{m}$ sections from mature green fruit of crisp texture southern highbush blueberry genotypes (100× magnification): (A) FL98-325, (B) 'Sweetcrisp', (C) FL07-100, (D) FL06-244. Sections were stained with Safranin O and Aniline Blue.

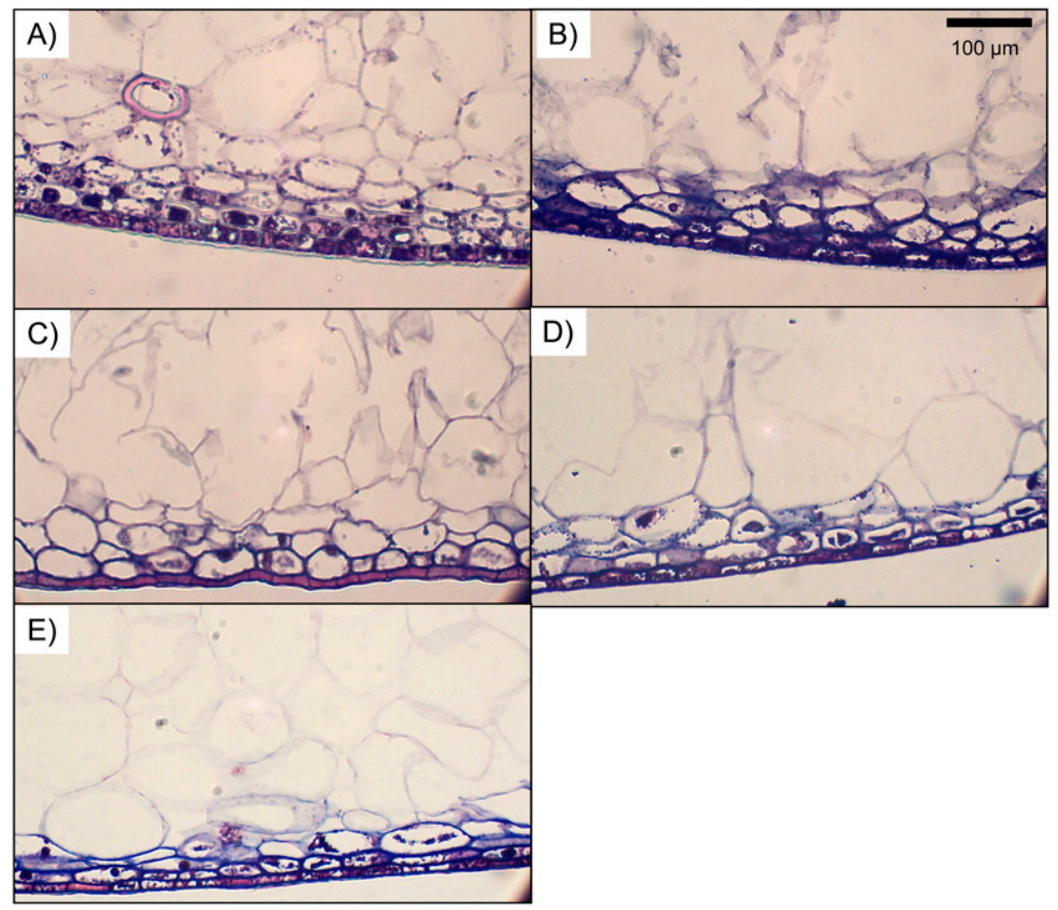

Fig. 3. Microscopic images of $12-\mu \mathrm{m}$ sections from ripe blue fruit of standard texture southern highbush blueberry genotypes (100× magnification): (A) 'Springhigh', (B) 'Windsor', (C) 'Star', (D) FL06-245, (E) 'Raven'. Sections were stained with Safranin O and Aniline Blue.

(FL06-245, 'Windsor', Springhigh', and 'Star') were harvested at the mature green and ripe blue stages of development as described by Shutak et al. (1980). 'Raven' was also included in the study because it has very firm texture but had not been subjectively evaluated as crisp before trained panel evaluations. Genotypes from different pedigrees were preferentially selected; however, one full-sib pair (FL06-244 and FL06-245) was evaluated to compare cellular structure of a crisp and non-crisp genotype from the same genetic background.

Microscopy. A $0.23-\mathrm{mm}$-wide steel razor was used to remove the calyx and stem end of each fruit $(\approx 1 \mathrm{~mm}$ width) before being immersed and stored in FAA solution (10 formaldehyde:5 glacial acetic acid:35 ethyl alcohol). These small areas of epidermis were removed to facilitate fixative infiltration. Fruit were stored in fixative for 1 to 3 months, and the fixative was refreshed several times during this period. Radial sections $(\approx 3 \mathrm{~mm}$ width) were taken using a $0.23-\mathrm{mm}$-wide steel razor and sections were dehydrated in a graded ethanol series (30\%, 40\%, 50\%, 60\%, 70\%, 80\%, 90\%, 95\%, and $100 \%$ for $45 \mathrm{~min}$ ) followed by paraffin infiltration and embedding using tert-butyl alcohol as an intermediate solvent (Ruzin, 1999). Sections of 12 to $14 \mu \mathrm{m}$ were obtained using a $0.25-\mathrm{mm}$ steel microtome blade on a rotary microtome and were mounted on glass slides. The mounted sections were deparaffinized with Histoclear II (National Diagnostics, Atlanta, GA), stained with Safranin $\mathrm{O}$ and Aniline Blue, and were permanently mounted with a cover glass using DePex Mounting Medium (Fisher Scientific, Pittsburgh, PA).

A light microscope (Ortholux; Leica Microsystems, Wetzlar, Germany) was used to visualize samples using the $10 \times$ and $40 \times$ objectives. Images were captured with a Moticam $10001.3 \mathrm{M}$ pixel camera (Motic, Hong Kong, China) and visualized using Motic Images Plus 2.0 ML software.

IMAGE ANALYSIS. The total number of stone cells to a depth of $1.2 \mathrm{~mm}$ from the epidermis was counted in a whole section of four berries from each maturity stage and genotype. Stone cells were identified as cells with a thick cell wall that was darkly stained with Safranin O. Cell dimensions were measured using the ruler function in Photoshop CS5 (Adobe Systems, San Jose, CA). Cell height and width were measured and used to calculate the cell area of 40 cells in the outer four cell layers of whole sections of mature green fruit from each genotype and 40 cells in the outer three cell layers of whole sections of ripe fruit from each genotype.

Statistical analysis. Data for cell area were analyzed as a factorial analysis of variance with two levels for texture (crisp and standard), nine levels for genotype (FL98-325, FL06-244, FL06-245, FL07100, 'Raven', 'Springhigh', 'Star', 'Sweetcrisp', and 'Windsor') nested within texture, and three or four cell layers (three for blue fruit, four for green fruit). Mean separation was performed using Tukey's honestly significant difference (HSD) test $(P \leq 0.05)$. Analysis was done with JMP (Version 10; SAS Institute, Cary, NC). Data for stone cell number were analyzed with SAS (Version 9.2; SAS Institute) using Proc GLM and Tukey's HSD $(P \leq 0.05)$.

\section{Results and Discussion}

The natural logarithmic transformation was used for analysis of cell area measurements. In mature green fruit samples, there 


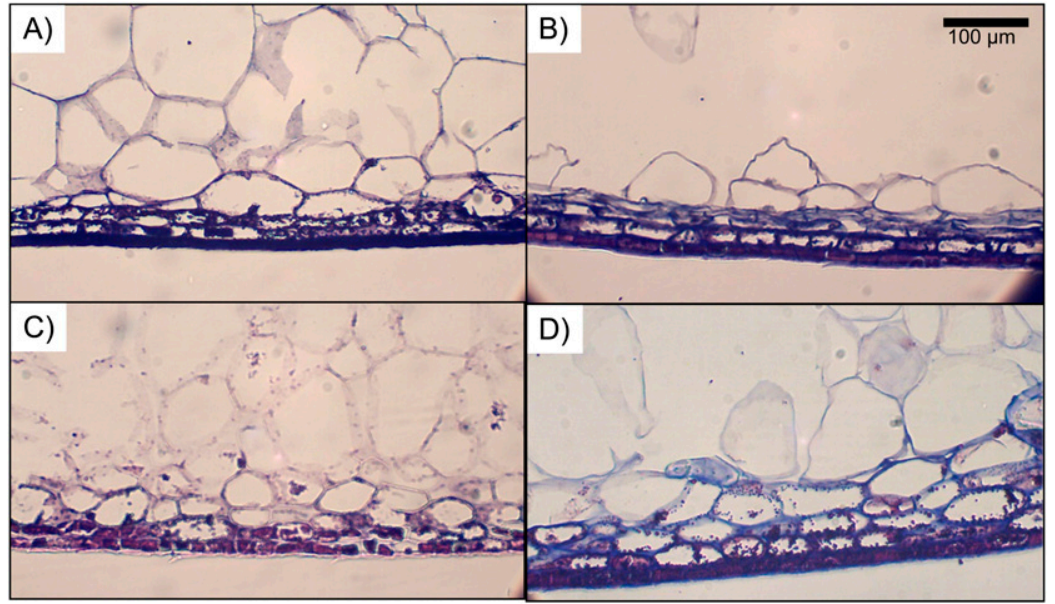

Fig. 4. Microscopic images of $12-\mu \mathrm{m}$ sections from ripe blue fruit of crisp texture southern highbush blueberry genotypes (100× magnification): (A) FL98-325, (B) 'Sweetcrisp', (C) FL07-100, (D) FL06-244. Sections were stained with Safranin O and Aniline Blue.

Table 2. Mean number of stone cells per fruit at the mature green and ripe blue stages of maturity for southern highbush blueberry genotypes with standard and crisp fruit texture.

\begin{tabular}{llcc}
\hline & & \multicolumn{2}{c}{ Stone cells (no.) } \\
\cline { 3 - 4 } Genotype & Texture & Mature green fruit & Ripe blue fruit \\
\hline FL06-244 & Crisp & $95 \mathrm{a}^{\mathrm{z}}$ & $56 \mathrm{a}$ \\
FL06-245 & Standard & $67 \mathrm{ab}$ & $22 \mathrm{~b}$ \\
'Raven' & Standard & $51 \mathrm{bc}$ & $23 \mathrm{~b}$ \\
'Windsor' & Standard & $17 \mathrm{~cd}$ & $4 \mathrm{bc}$ \\
'Springhigh' & Standard & $12 \mathrm{~d}$ & $13 \mathrm{bc}$ \\
'Sweetcrisp' & Crisp & $7 \mathrm{~d}$ & $17 \mathrm{bc}$ \\
FL98-325 & Crisp & $0 \mathrm{~d}$ & $0 \mathrm{c}$ \\
FL07-100 & Crisp & $0 \mathrm{~d}$ & $0 \mathrm{c}$ \\
'Star' & Standard & $0 \mathrm{~d}$ & $0 \mathrm{c}$
\end{tabular}

${ }^{2}$ Tukey's honestly significant difference grouping for least square (LS) means. LS means with different letters within a column are significantly different at $P \leq 0.05$.

was no significant difference in overall cell area based on texture type. However, there were significant differences for the genotype $(P=0.009)$ and cell layer $(P<0.0001)$ main effects. The genotype-by-cell layer interaction was significant $(P<0.0001)$. For all cultivars the trend was for larger cell area with each successive layer from the epidermis (Table 1; Figs. 1 and 2). The significant genotype-by-cell layer interaction was the result of the variation in the degree of cell area increase in each cell layer by genotype. There was no significant interaction between texture type and cell layer $(P=0.857)$.

At the ripe blue fruit development stage, there was a significant difference in overall cell area based on texture type $(P=$ $0.0263)$ with crisp texture genotypes having a smaller average cell area compared with standard texture genotypes (1148 \pm 848 and $1252 \pm 773 \mu \mathrm{m}^{2}$, respectively). Genotype and cell layer also had a significant impact on cell area $(P<0.0001)$. Like with green fruit, there was a significant genotype-by-cell layer interaction $[P<0.0001$ (Table 1)] but the texture type-by-cell-layer interaction was non-significant $(P=0.307)$. Again, the trend was for cell area to increase with successive layers from the epidermis (Figs. 3 and 4), and the interaction was the result of change in the degree of cell area increase in each successive cell layer by genotype.

The average cell area ranged from 436 to $718 \mu \mathrm{m}^{2}$ in the epidermal cell layer of mature green fruit and from 429 to $712 \mu \mathrm{m}^{2}$ in the epidermal cell layer of ripe blue fruit (Table 1). This indicated that there was not a dramatic increase of cell area in the epidermal layer of berries as they ripened from mature green to fully ripe fruit, which is consistent with previous results suggesting that cell division persists in the epidermis, whereas mesocarp cells stop dividing and increase only in size during the latter stages of ripening (Harker et al., 1997). The berries of FL06-244 and 'Star', when compared with all other genotypes of mature green and ripe blue fruit, respectively, had the largest difference in average cell area between the epidermis and second cell layer. For all genotypes, average cell area successively increased in the second, third, and fourth cell layers from the epidermis of both mature green and ripe blue fruit (Figs. 1 to 4; Table 1). Johnson et al. (2011) found that differences in fruit size among genotypes were largely the result of an increase in cell number, although they noted a large range in cell size for mesocarp cells. The present analysis, which is limited to the epidermis and outer-most layers of mesocarp cells, showed significant differences among genotypes at both immature and mature berry development stages in all cell layers examined except the second layer internal from the epidermis in green fruit.

An overall reduction in cell area as a result of texture type was observed in ripe blue fruit but not mature green fruit. Although the crisp genotype FL06-244 had the greatest average cell area in the epidermis, it was similar to other crisp genotypes with smaller average cell area in the internal cell layers (Table 1; Fig. 4). FL07-100 consistently had the smallest average cell area (Table 1- Fig. 4). Differences in fruit size of a genotype could impact cell area measurements. For example, FL07-100 often has smaller average fruit size than other genotypes used in the study and could have resulted in the consistent small cell area recorded. In contrast, 'Raven' fruit typically average 3.5 to $4.0 \mathrm{~g}$, but average cell areas were not significantly different from FL07-100. Interestingly, 'Raven' was included in the study as a genotype having a texture subjectively rated as standard. However, a trained sensory panel found its texture to be equal to the crisp genotype FL98-325, and firmness measurements of 'Raven' exceeded those of FL98-325 (Blaker et al., 2014). The combination of previous sensory analysis and similarity to other crisp genotypes in average cell area suggest 'Raven' may need to be reclassified as having crisp fruit texture.

The difference in average cell area between mature green and ripe blue fruit is indicative of cell expansion during the ripening process. Although cell area could not be measured in the same fruit during ripening, we observed that the largest differences in the epidermal cell layer between mature green and ripe blue fruit were in three standard texture genotypes (FL06-245, 'Springhigh', and 'Star') suggesting an earlier cessation of cell division in the epidermis (Table 1). Whereas these observations are not conclusive, they offer a possible explanation of how cell division and cell expansion in the 


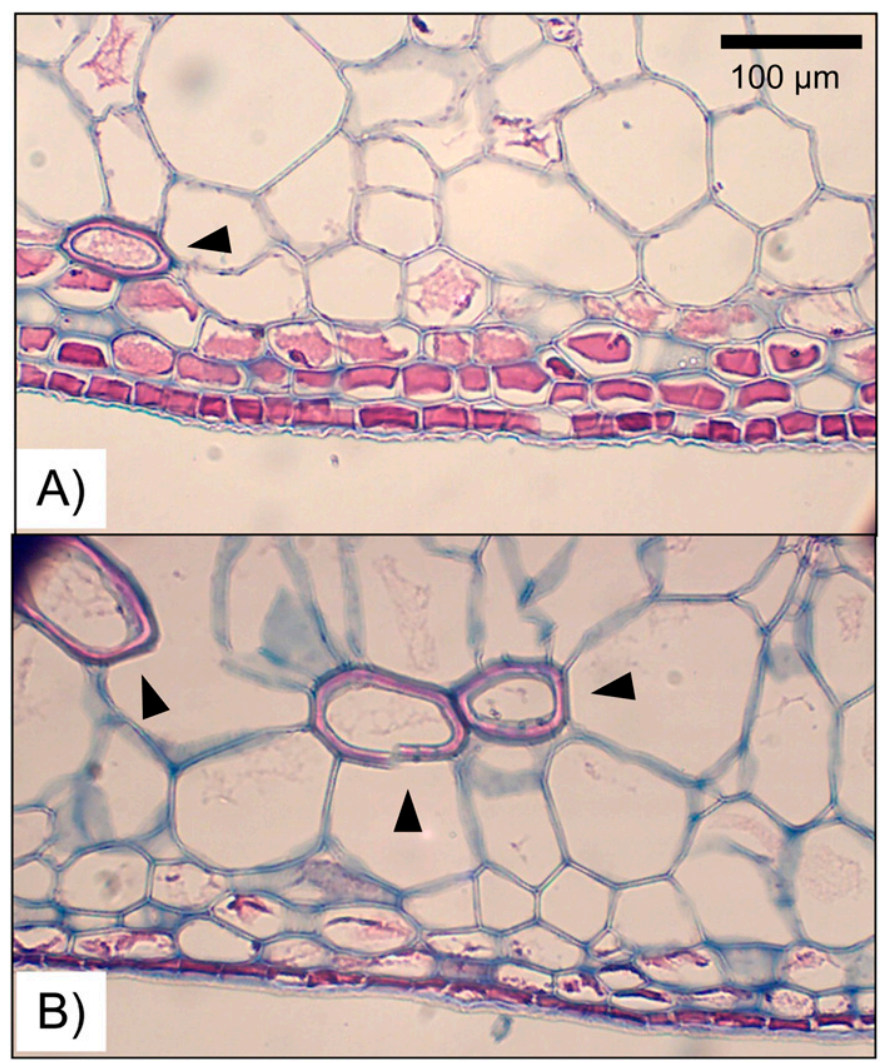

Fig. 5. Microscopic images of $12-\mu \mathrm{m}$ sections from southern highbush blueberry genotypes that include stone cells (100× magnification): (A) crisp genotype FL06-244 and (B) standard texture genotype FL06-245, a full-sib of FL06-244. Arrows indicate stone cells. The thickened cell walls of stone cells are pink after staining with Safranin O. Note that the stone cells occur singly or in pairs and are located just below the epidermal cells of the fruit.

epidermal layer of crisp and standard texture blueberries differ during ripening.

Stone cells were observed in the sections of some SHB genotypes ('Springhigh', FL06-245, 'Windsor', 'Raven', FL06244, and 'Sweetcrisp') that were evaluated (Table 2). Stone cells were found singly or in pairs as previously reported (Allan-Wojtas et al., 2001; Fava et al., 2006; Gough, 1983), but no clusters were observed (Fig. 5). The average number of stone cells in a single slide section ranged from zero to 95 stone cells (Table 2). Two crisp genotypes (FL98-325 and FL07-100) did not have any stone cells, whereas 'Sweetcrisp' had a moderate number of stone cells (an average of seven per mature green fruit section and 17 per ripe blue fruit section). The crisp genotype FL06-244 had more stone cells/berry than any other genotype evaluated. Two full-sibs, FL06-244 (crisp) and FL06-245 (standard texture), both exhibited a high frequency of stone cells (Table 2), which suggests that this trait is genetically regulated. As a whole, the crisp genotypes that were evaluated here did not have a higher frequency of stone cells than standard texture genotypes, suggesting that stone cells located just below the epidermal layer are not correlated with crisp texture in blueberry.

\section{Literature Cited}

Allan-Wojtas, P.M., C.F. Forney, S.E. Carbyn, and K. Nicholas. 2001. Microstructural indicators of quality-related characteristics of blueberries - An integrated approach. Food Sci. Technol. (Campinas.) 34:23-32.

Batisse, C., M. Buret, and P.J. Coulomb. 1996. Biochemical differences in cell wall of cherry fruit between soft and crisp fruit. J. Agr. Food Chem. 44:453-457.

Blaker, K., A. Plotto, E. Baldwin, and J. Olmstead. 2014. Correlation between sensory and instrumental measurements of soft and crisp textured southern highbush blueberries. J. Sci. Food Agr. doi: $10.1002 /$ jsfa. 6626 .

Clark, J.R. and C.E. Finn. 2010. Register of new fruit and nut cultivars: List 45. HortScience 45:716-756.

Darnell, R.L., G.W. Stutte, G.C. Martin, G.A. Lang, and J.D. Early. 1992. Developmental physiology of rabbiteye blueberry. Hort. Rev. 13:339-405.

Esau, K. 1977. Anatomy of seed plants. Wiley, New York, NY.

Fava, J., S.M. Alzamora, and M.A. Castro. 2006. Structure and nanostructure of the outer tangential epidermal cell wall in Vaccinium corymbosum L. (blueberry) fruits by blanching, freezingthawing and ultrasound. Food Sci. Technol. Intl. 12:241-251.

Ghiani, A., N. Negrini, S. Morgutti, F. Baldin, F.F. Nocito, A. Spinardi, I. Mignani, D. Bassi, and M. Cocucci. 2011. Melting of 'Big Top' nectarine fruit: Some physiological, biochemical, and molecular aspects. J. Amer. Soc. Hort. Sci. 136:61-68.

Godoy, C., G. Monterubbianesi, and J. Tognetti. 2008. Analysis of highbush blueberry (Vaccinium corymbosum L.) fruit growth with exponential mixed models. Sci. Hort. 115:368-376.

Gough, R.E. 1983. The occurrence of mesocarpic stone cells in the fruit of cultivated highbush blueberry. J. Amer. Soc. Hort. Sci. 108:1064-1067.

Gough, R.E. 1994. The highbush blueberry and its management. Haworth Press, Binghampton, NY.

Harker, F.R., R.J. Redgwell, I.C. Hallett, S.H. Murray, and G. Carter. 1997. Texture of fresh fruit. Hort. Rev. 20:121-224.

Johnson, L.K., A. Malladi, and D.S. NeSmith. 2011. Differences in cell number facilitate fruit size variation in rabbiteye blueberry genotypes. J. Amer. Soc. Hort. Sci. 136:10-15.

Mann, H., D. Bedford, J. Luby, Z. Vickers, and C. Tong. 2005. Relationship of instrumental and sensory texture measurements of fresh and stored apples to cell number and size. HortScience 40:1815-1820.

Mehra, L.K., D.D. MacLean, A.T. Savelle, and H. Scherm. 2013. Postharvest disease development on southern highbush blueberry fruit in relation to berry flesh type and harvest method. Plant Dis. 97:213-221.

Okie, W.R. 1999. Register of new fruit and nut varieties-List 39. HortScience 34:181-205.

Padley, L. 2005. Firmness and storage characteristics of crisp-textured blueberries. MS thesis, Univ. Florida, Gainesville, FL.

Ruzin, S.E. 1999. Plant microtechnique and microscopy. Oxford Univ. Press, New York, NY.

Sato, A., M. Yamada, and H. Iwanami. 2006. Estimation of the proportion of offspring having genetically crispy flesh in grape breeding. J. Amer. Soc. Hort. Sci. 131:46-52.

Scalzo, J., S. Dierking, W. Dierking, S. Miller, C. Edwards, and P. Alspach. 2009'Hortblue Poppins': New cultivar for the home garden. Acta Hort. 810:157-162.

Shutak, V.G., R.E. Gough, and N.D. Windus. 1980. The cultivated highbush blueberry: Twenty years of research. Rhode Island Agr. Expt. Sta. Bul. 428.

Takeda, T., G. Krewer, C. Li, D. MacLean, and J.W. Olmstead. 2013. Techniques for increasing machine-harvest efficiency in blueberries. HortTechnology 23:430-436.

Tong, C., D. Krueger, Z. Vickers, D. Bedford, J. Luby, A. El-Shiekh, K. Shackel, and H. Ahmadi. 1999. Comparison of softening-related changes during storage of 'Honeycrisp' apple, its parents, and 'Delicious'. J. Amer. Soc. Hort. Sci. 124:407-415. 